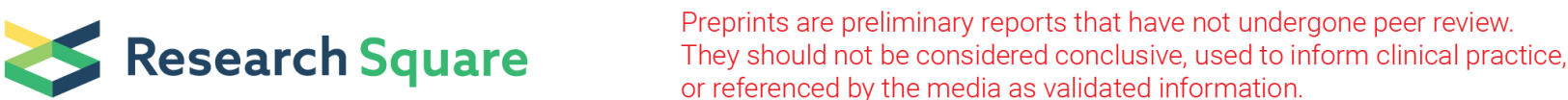

\section{An Integrated Methodology for Green Human Resource Management in Construction Industry}



Research Article

Keywords: Green Human Resource, Environmental Management, Sustainable Development, Meta-Synthesis, Structural Equation Modeling

Posted Date: March 1st, 2022

DOI: https://doi.org/10.21203/rs.3.rs-1277101/v1

License: (c) (7) This work is licensed under a Creative Commons Attribution 4.0 International License. Read Full License 


\section{Abstract}

Today, by increasing public awareness about environmental issues and pressures from governments and other stakeholders companies have dealt with environmental challenges more than ever. This paper focuses on environmentally sustainable performance using an integrated method based on metasynthesis, Delphi, and structural equation modeling (SEM) methods are utilized in different phases of the methodology. In the first phase, an in-depth review of green human resources management (GHRM) literature is conducted based on the meta-synthesis method and as a result, 38 codes were extracted. Then, to adapt and customize the codes with the nature of the construction industry, 2 rounds of the Delphi method are applied to collect the expert judgment from a panel of 15 industry professionals, resulting in 21 codes in 7 categories. Finally, to verify the proposed model the data from 33 Iranian construction companies were collected and by using SEM, 15 factors in 5 categories are presented. The findings indicated that among 9 main GHRM components extracted from the literature, just 5 components including green recruitment and selection, green performance management, green- reward, green-based employee empowerment, and green training have significant and positive relationships with GHRM. The paper also provides some managerial insights and some future directions.

\section{Introduction}

In recent decades, global warming and climate change have had profound impacts on people's lives which demands more attention to the environmental issues from companies (Mishra, 2017; Jabbour and de Sousa Jabbour, 2016). Furthermore, the mounting pressures from various stakeholders such as consumers, governments, and environmental activists have forced companies to initiate environmentally friendly practices (Mousa and Othman, 2020). Companies need to increase their abilities to address stakeholder's environmental concerns to be profitable and survive in the long term (Kawakami et al. 2015; Gardas et al. 2019; Walker et al., 2014). The incorporation of environmental issues in companies' strategic tasks can increase their competitive advantage and lead to sustainable development (Govindan et al., 2013; Sarkar et al., 2020; Vandchali et al., 2021a, 2021b).

Addressing the environmentally sustainable performance issues, and promoting green organizations is a sustainable human resource management (HRM) approach that ensures the sustainable development of organizations and can be achieved by adopting new ecological techniques by using innovative strategies and the human capital of organizations (Chams and García-Blandón, 2019). However, companies need to have competent employees who have passion, knowledge, and skills to manage environmental issues. Integrating green management and HRM can be considered as a green revolution in traditional principles of HRM, motivating the scientific society in the field of green human resource management (GHRM) (Ansari et al., 2021; Al-Ghazali and Afsar, 2021; Nejati et al., 2017; Jabbour, 2011 and 2013; Dutta, 2012; Gholami et al., 2016; Sarkis, 2012; Yu et al., 2020). Effective environmental management and a company's competitiveness are dependent on HRM (Ehnert, 2009; Phipps et al., 2013; Pohjola, 2001). GHRM is defined in HRM practices, including green employment, green learning, green performance, and green services compensation (Zaid et al., 2018). Masri and Jarron (2017) defined GHRM in terms of HRM actions that lead to increased HR commitments to sustainable environmental practices (Masri and Jaaron, 2017). GHRM is an approach to extend the scope of HRM applications to minimize the damages that may be caused by the activities of the firms in all business processes (Zaid et al., 2018).

The employees' environmentally friendly behavior will improve the companies' sustainable performance (Lo et al., 2012). GHRM practices affect employees' environmentally friendly behavior to achieve environmental sustainability (Kim et al., 2019). Implementing GHRM practices can ensure the success of the environmental performance of an organization that has a key role in developing organizational sustainability (Pham et al., 2020a). GHRM practices as an approach for sustainable development objectives of the organization facilitate the implementation of green practices and policies by various practices of compensation, recruitment, rewards, and exit policies (Nisar et al., 2021). Greening an organization is a novel shift that requires commitment from both the management and the employees. It does not happen by only practices affected by GHRM but also by the improvement of green behaviors among the members of an organization (DuBois and Dubois, 2012).

Recently, many academicians and practitioners have focused on the importance of employing competent, qualified, and skillful employees as an effective way to achieve sustainable performance through GHRM (Yong et al., 2019). Reviewing the related literature shows that manufacturing and service companies use GHRM to improve their sustainable environmental performance (Raut et al., 2020). Scholars and practitioners such as Ghouri, Mani, Khan, Khan, and Srivastava (2020), Siyambalapitiya et al., (2018), Gilal et al., (2019), and Nisar et al., (2021) tried to extend the GHRM practices into the different manufacturing and service industries. Ghouri et al. (2020) assessed the key determinants of GHRM and investigate its impact on environmental performance and business performance in the Malaysian manufacturing industry. Siyambalapitiya et al. (2018) proposed a model for GHRM in Sri Lanka's tourism industry; Gilal et al. (2019) extended GHRM practices into the higher education institutions. Recently, Nisar et al. (2021) investigated the role of green intellectual capital and pro-environmental behavior in Malaysian hotels. An integrated data envelopment analysis (DEA) and life cycle assessment (LCA) technique was offered by Tavana et al. (2021) to conduct the performance measurement in green construction management.

Construction industry is known for its high impact on the environment which ingests more than $40 \%$ of the total global energy and results in more than $40 \%$ of total global GHG emissions (Yin and Li, 2019). However, there is a lack of research in finding the appropriate GHRM initiatives in the construction industry (Buckly and Kalarickal, 2005; Takahashi, 2009; Shinkareva et al., 2020). The construction certainly harms the environment; it can arise from the non-green human behaviors toward environmental degeneration. Organizations can reduce environmental degradation by expanding the scope of GHRM practices (Yong et al., 2019). Construction companies have always been in the front line as a result of the environmental impacts caused by their construction activities (Luciano et al., 2021). This motivates them to increase their environmental practices to address environmental concerns. Therefore, there is a need for paying attention to GHRM in the construction industry. This paper designs a model for GHRM in the field of construction to maintain equal opportunities for current and future generations to effectively use environmental resources. The main contributions of the paper are outlined as follows:

- Designing a GHRM model for the construction industry,

- Enriching the GHRM literature by developing GHRM to the construction industry,

- Using a hybrid approach based on meta-synthesis, Delphi, and SEM method to design and verify the GHRM model for the construction industry, 
- Providing managerial insights to the companies in the construction industry to reach sustainable performance by presenting a model of effective GHRM factors in the construction industry.

The rest of this paper is structured as follows: in section 2, the GHRM literature is reviewed and related components are defined. The research methodology and the related phases are presented in Section 3. In section 4, the data are analyzed and the GHRM model is developed. Finally, conclusions, managerial insights, and future directions are presented in Section 5.

\section{Literature Review}

Using the meta-synthesis method, GHRM literature from 2011 to 2021 is extensively reviewed. Although the starting date of using GHRM related concepts in the construction industry refers to 2004 by Tam et al (2004), the number of papers before 2011 is very low. Therefore, the year 2011 was selected as the starting point for collecting the relevant data and the year 2021 was selected as the endpoint. This specific duration has been employed to include the most recent research studies in view of the increase in publications that have addressed this highly important topic. The results of the literature review are elaborated in the following sections.

\subsection{Green Human Resource Management}

With the formation of the HRM term, Jackson et al. (2011) conducted the first specific HRM review. They highlighted the critical role of HRM activities in assisting leading companies to move towards environmental policies and strategies. However, the number of works in this field has been increased in recent years. Table 1, provides several definitions of GHRM in different studies.

Table 1

GHRM definitions.

\begin{tabular}{|c|c|}
\hline Reference & Definitions \\
\hline $\begin{array}{l}\text { Jabour et al. } \\
(2010)\end{array}$ & $\begin{array}{l}\text { GHRM consists of greening the operational aspects of human resources management (for example, job evaluation, employment, } \\
\text { education, performance measurement, and rewards) }\end{array}$ \\
\hline Wagner (2011) & GHRM is an approach that meets a company and society's needs without damaging the environment. \\
\hline $\begin{array}{l}\text { Teixeira et al. } \\
(2012)\end{array}$ & $\begin{array}{l}\text { GHRM adjusts different practices for GHRM (like employment, selection, education, performance, and rewards measurement) to } \\
\text { achieve the company's green management goals. }\end{array}$ \\
\hline $\begin{array}{l}\text { Renwick et al. } \\
\text { (2013) }\end{array}$ & $\begin{array}{l}\text { GHRM refers to HRM practices aimed at environmental and ecological influence of the firms and it is linked with firm environmental } \\
\text { strategy and green behaviors of employees. }\end{array}$ \\
\hline Opatha (2013) & $\begin{array}{l}\text { GHRM refers to all of the systematic operations used in implementing, maintaining, and developing. Its purpose is to green the } \\
\text { company's employees. }\end{array}$ \\
\hline $\begin{array}{l}\text { Opatha and } \\
\text { Arulrajah (2014) }\end{array}$ & $\begin{array}{l}\text { GHRM refers to policies, systems, and performances that want to green the employees to achieve personal, social, natural, and } \\
\text { organizational environment benefits. }\end{array}$ \\
\hline $\begin{array}{l}\text { Paille et al. } \\
(2014)\end{array}$ & $\begin{array}{l}\text { GHRM empowers human resources with environmental efficiency by adjusting the human resources management techniques and } \\
\text { systems to improve the green principles. }\end{array}$ \\
\hline $\begin{array}{l}\text { Mehdi Yousef et } \\
\text { al. (2015) }\end{array}$ & GHRM emphasizes orientation to change the processes and outputs of the company. \\
\hline $\begin{array}{l}\text { Gholami et al. } \\
\text { (2016) }\end{array}$ & GHRM is a new field that tries to achieve environmental management purposes by cooperating with HRM operations. \\
\hline $\begin{array}{l}\text { Pinzone et al. } \\
\text { (2016) }\end{array}$ & GHRM refers to environmental HRM aspects that lead to improved environmental performance vital. \\
\hline Oh et al. (2016) & $\begin{array}{l}\text { GHRM directs organization's strategic orientation towards environmental protection and asks top management to engross } \\
\text { organizational processes and practices that empowers people to take part in green job behaviors to reduce environmental pollutions } \\
\text { at the workplace. }\end{array}$ \\
\hline $\begin{array}{l}\text { Masri, and } \\
\text { Jaaron (2017) }\end{array}$ & $\begin{array}{l}\text { GHRM concentrates on firm environmental management practices wherein green HRM behaves as a platform to connect HRM } \\
\text { practices to environmental management activities of the firm. }\end{array}$ \\
\hline $\begin{array}{l}\text { Bombiak and } \\
\text { Marciniuk-Kluska } \\
\text { (2018) }\end{array}$ & Incorporating environmental practices into the area of human resource policy, referred to as GHRM. \\
\hline $\begin{array}{l}\text { Vijai and Joyce } \\
(2021)\end{array}$ & GHRM involves the alignment of the firm's HRM practices to the environmental management system. \\
\hline
\end{tabular}

According to the above-mentioned definitions by various authors, GHRM consists of traditional HR operations (e.g., job evaluation, employment, education, performance, and rewards measurement) in which the main focus is on environmental purposes and strategic aspects of the HRM (Jabbour et al., 2010). By focusing on the environmental criteria, Raut et al. (2020) analyzed the HR performance in the electronic service sector in India. Using the interpretive structural modeling method (ISM method) and the MICMAC analysis, they found that green organizational culture and green development and education are the most effective green human resources in India's electronic service sector. Singh et al. (2020) investigated the impacts of GHRM on 309 active small and mediumsized companies. The results showed a significant relationship between GHRM and environmental performance. Yong et al. (2019) reviewed the GHRM literature from 2007 to 2019 and by reviewing 70 papers, they found that GHRM has significant impacts on the individual and organizational environmental performances. Furthermore, there has been more interest in analyzing GHRM in developing countries. Siyambalapitiya et al. (2018) identified GHRM practices, 
which impacted environmental management in the Sri Lanka tourism sector. The results showed that green employment is the most important factor in their environmental management system. Masri and Jaaron (2017) examined the impacts of GHRM in manufacturing companies in Palestine. They reviewed 110 manufacturing companies including food, chemical, and medicines manufacturers to recognize the effective practices of GHRM in environmental performance. The qualitative part of the research identified 6 components of the GHRM, including green employment, green education and development, green performance management, green rewards and service compensation, green empowerment and participation, and green organizational culture management. The quantitative part of their research showed that the "green employment" and "green learning and development" factors had the highest and the lowest impacts on the companies' environmental performance. Rayner and Morgan (2017) evaluated the employees' environmental knowledge and measured their understanding of their ability, motivation, and opportunities. Collecting data from 394 employees of 5 Australian companies, they found that positive environmental ability, motivation, and opportunity might lead to green behavior, and it is more common at home compared to being at work. Tang et al. (2017) designed a tool for measuring five components of GHRM including green employment, green education, green performance management, green paying and rewards, and green participation. Dumont et al. (2017) investigated the impacts of GHRM practices on green behavior by highlighting the intermediary role of the green organizational atmosphere and individual green values. They collected data from a Chinese and an Australian multinational company. The results showed that the green organizational atmosphere and individual green values have direct and indirect impacts on the green behaviors of the employees. Arulrajah et al. (2015) reviewed the respective green twelve tasks of HRM including the job description, job analysis, HR planning, employment, choices, inculcation, performance measurement, education and development, disciplinary management, health, and safety management, and employee's

\section{communication.}

\subsection{Components of GHRM}

A review in GHRM literature indicated that 9 GHRM components such as green organizational culture, green recruitment, and selection, green employee involvement, green employee empowerment, green performance management, green reward, health and safety management, green discipline management, green training, and development are the widely used components. Table 2 provides more details about the GHRM components. 
Table 2

Explanation of GHRM components.

\section{GHRM Definitions and indicators}

component

Green

organizational

Green organizational culture is defined as "the pattern of shared basic assumptions about environmental issues and environmental

culture

management (Marshall et al ,2015). Green organizational culture includes shared beliefs, values, norms, symbols, and social stereotypes about organizational environment management and shapes the standard behavior expected from the individuals (Chang, 2015). In the present study, green organizational culture is measured through top management support of green practices, green organizational mission, green organizational values, green punishment system, and financial covering green activities indicators.

Green

recruitment

and selection

Green

employee

involvement

Green

employee

empowerment

Employing people who commit to the environment plays a vital role in the company's greening process (Jabbour and Santos, 2008). If
companies tend to achieve their environmental policies, their employees need to have the right attitude towards the environment. In the
present study, green recruitment and selection are measured through the green job description, green recruitment process, green-based applicants evaluation, green recruitment messages, and green job designing indicators.

Scholars outlined that employees who are involved in issues related to the environment have more knowledge regarding environmental issues. Furthermore, they are more capable to tackle the problems related to the environment, which leads to improved environmental performance (Rothenberg, 2003). In the present study, green involvement is measured through clear green vision, green learning climate, various communication channels, offering green practices, encouraging green involvement indicators.

Green employee empowerment also contains employee involvement in pursuing green organizational tasks (Longoni et al., 2014; May and Flannery 1995). Green employee empowerment is a potential mediator that represents the influence on employees' motivational levels for pursuing green practices (Tariq et al., 2016). In the present study, green employee empowerment is measured through joint consultations for environmental issues problem solving, holding workshops to enhance environmental behavior, providing conditions to exchange tacit knowledge, involving to formulating environmental strategy, and using teamwork to increase environmental awareness indicators.

Green

performance

management

Green performance measurement is important for companies to manage their actual environmental performance in the long term. Therefore, green performance measurement should be performed independently or implemented in alignment with company performance measurement (Jabbour and Santos, 2008). In the present study, green performance management is measured through green goals transparency, clarifying green criteria in employee performance evaluation, green-based employee performance assessment, providing regular feedback for environmental performance, green organizational commitment, and green information system indicators.

Green reward Green rewards refer to a system of financial and non-financial rewards for employees with a distinct potential to contribute to environmental management" (Jabbour et al., 2010). In the present study, green rewards are measured through the monetary and nonmonetary rewards for environmental achievements, reward for innovative environmental achievement, and rewards for innovative environmental suggestion indicators.

Health and

safety

management

Health management and green safety can go beyond the traditional safety and health management in HRM. It consists of the traditional practices of safety and health management and some aspects of environmental management. Many companies tend to green their safety and health management. The role of safety and health management system is to ensure that the work environment is green for the employees. In a green workplace, the company pays attention to environmental sensibility, social responsibility, and efficiency in using the resources (Jabbour and Santos, 2008). In the present study, health and safety management is measured through creating green health conditions, green-based workplace design, and green-based job design indicators.

Green

discipline

management

Green discipline management is defined as fining or punishing employees for noncompliance on targets in environmental management (Nisar et al., 2021). In the present study, green employee discipline management is measured through establishing green rules, determining green behavior, and green punishment indicators.

Green training and

The companies' capability to promote employees' skills is a key factor in HR strategic development (Ellinger and Ellinger, 2014). They need to focus on environmental learning (Jabbour, 2013), which changes the mindset and behavior of the employees. By developing environmental policies, companies can decrease the negative effects on the environment, create a conscious environmental culture (Daily and Huang, 2001), increase the environmental knowledge of the employees, and provide the required environmental skills and knowledge for the employees (Renwick et al., 2012). In the present study, green training and development are measured through providing training opportunities, giving the first priority to green training programs, and holding online training to reduce paper cost and COVID-19 outbreak.

\section{Research Methodology}

The present study aims to present a model for contributing factors of GHRM in the construction industry. As shown in Figure 1, this study used a mixed approach including meta-synthesis, Delphi, and SEM methods, to design a model for GHRM in the construction industry in three phases. In the first phase, to identify GHRM contributing factors an in-depth literature review through the meta-synthesis method was conducted. In the second phase, to adopt and customize GHRM factors with the construction industry, the Delphi method and the initial GHRM model for the construction industry were presented. Finally, in the last phase, to validate the initial model, SEM methods based on partial least square (PLS) were used. In the following, the steps of each phase are explained. Figure 1 explains the three phases of this study, briefly.

\subsection{Identifying GHRM Factors Through the Meta-synthesis Method}

Using seven steps of the Sandelowski and Barroso (2016) pattern in the first phase, we identified GHRM components from the related literature between 2011 and 2021. The steps of the meta-synthesis method are presented in following:

\section{Step 1. Determining research question}

The first step of the meta-synthesis method is to develop the main research question.

\section{Step 2. Reviewing the literature in a systematic way}

Step 3. Evaluating and selecting the suitable papers 
A tool used for evaluating the quality of primary perusal of the qualitative research is called The Critical Appraisal Skills Programme tool (CASP). The papers were first evaluated and rated based on 10 criteria/questions as shown in Table 3. The maximum score of every criterion/question was considered 5. Then, 'the sum of the scores that each paper earned was calculated accordingly and the papers which the sum of their scores was less than 25 were eliminated.

\section{Step 4. Extracting results}

In this step, we used a research question to extract the relevant codes from the selected papers.

\section{Step 5. Analyzing and synthesizing the qualitative findings}

After extracting the codes, it is time to analyze, synthesize, and categorize the identified codes.

\section{Step 6. Quality control}

This step is about assessing the validity and internal reliability of the study's results. The validity of the research and coding process was assessed by academicians and industry experts. To assess the internal reliability of the coding process Cohen's Kappa coefficient was used.

Step 7. Presenting the findings.

Table 3

Evaluation of papers by CASP method.

\begin{tabular}{|l|}
\hline Questions \\
\hline Is the paper relevant to our study? \\
\hline Was the research design appropriate to address the aims of our study? \\
\hline Are the sample size and the sampling method suitable? \\
Are the sources and the way of collecting data suitable? \\
\hline How is the paper points' generalization capability? \\
\hline How accurate is the data analysis, and what is the method of data analysis? \\
Is the paper suitable in terms of expression clarity? \\
Are ethical principles of the paper like "mentioning the right references" and other ethical principles followed in the paper? \\
Is the relationship between the researcher and the participants considered in a suitable way? \\
\hline How do you evaluate the paper generally? \\
\hline
\end{tabular}

\subsection{Adopting and customizing the identified GHRM factors with the construction industry through the Delphi method}

In this phase, we utilized the experience of 15 industry experts with at least 10 years of experience in the field of the construction industry and GHRM principles in two rounds.

Round 1. Surveying the industry experts' opinion about the degree of relevance of extracted factors with the construction industry using 1 to 10 : The purpose of this round is to eliminate those codes which are irrelevant or less relevant to the activities in the construction industry. Firstly, a list of the extracted codes was given to the experts. Next, the experts were asked to select the components which are compatible with the industry. Then, the sum of every code's score, which is equivalent to the sum of the experts' votes was calculated. Those codes in which the sum of votes was less than the average votes received from the experts were eliminated from the list.

Round 2. Surveying the industry experts' opinion about the importance of each criterion using 1 to 5

In this round, it was asked from the experts to specify the degree of necessity and importance of the remained codes which may lead to achieving the research purposes.

\subsection{Validating proposed model using SEM method}

Finally, we validated the proposed model using SEM and second-order confirmatory factor analysis. To this end, we surveyed 229 managers from 33 Iranian construction companies using a 5 points Likert scale questionnaire. Then, we presented the final model of GHRM for the construction industry by conducting to following steps.

1. Measurement model: To assure that SEM can be effectively applied to our model, the validity and reliability of the results are examined. Composite reliability $(C R \geq 0.7)$ and average variance extracted $(A V E \geq 0.5)$ are two required factors for the convergent validity and construct correlation (Lin and Huang, 2009). The difference between measures of a construct and other constructs' measures will be compared via the convergent validity. To assess the divergent validity of the survey instrument we used a matrix that the square root of AVE for each construct is placed in the main diagonal of the matrix and correlation among the constructs is reported at bottom of the main diagonal. If the square root of AVE for a construct is greater than the correlation coefficient of the construct with other constructs, then the divergent validity will be accepted. 
2. Structural model: The structural model is utilized to evaluate the relationship between the latent variables. To test the relationship between the latent variables, we ran a bootstrapping procedure with a resampling rate of 500 (Hair et al., 2017) to obtain the $t$ values. If the $t$ value between two constructs is larger than |1.96|, then the relationship between them will be significant (Esposito Vinzi et al., 2010).

\section{Data Analysis And Presenting The Findings}

We analyzed findings in 3 consecutive phases using the three above-mentioned methods and the results are elaborated in the following sections.

\subsection{Data analysis using meta-synthesis method}

The primary green HRM model is developed by reviewing papers from the related literature using the meta-synthesis method in 7 steps.

Step 1: Since we intended to find the various components of a suitable GHRM model, we developed our research questions as

- What is the suitable GHRM model for the construction industry?

Step 2: We focused on English-written papers during the 10 recent years (2011 to 2021). The books, thesis, and conference proceedings papers were not included in this study's statistical population. The main keywords employed by this study include green human resource management, green HRM, green human resource, human factors, green practices, Green training and environmental HRM.

Step 3: As a result of evaluating the papers through the CASP, 39 papers are selected for further analysis. As shown in Figure 2, the procedure of filtering papers was based on their title, abstract, methodology, and the full content of papers.

Steps 4 and 5: After selecting the suitable papers, we used research questions to related extract codes from the texts. By reviewing 39 selected papers, we identified 44 primary codes which were categorized into 9 concepts.

Step 6: To evaluate the extracted codes, 2 experts' opinions were utilized. The study's processes were considered with 10 questions which had a scale that consisted of 4 choices ( $1=$ Weak, $2=$ Middle, $3=$ Good, and $4=$ Excellent) by two experts, and Cohen's kappa coefficient among the opinions of the experts was calculated by SPSS-26 software as shown in Table 4. Cohen's kappa coefficient is 0.706 , and it indicates the reliability of the study's results.

Table 4

Contingency coefficient among experts.

\begin{tabular}{|llllll|}
\hline \multicolumn{1}{|l|}{ Symmetric Measures } & \multicolumn{3}{l|}{} \\
\hline & Value & Asymp. Std. Error ${ }^{\mathrm{a}}$ & Approx. T $^{\mathrm{b}}$ & Approx. Sig. \\
\hline Measure of Agreement & Kappa & .706 & .172 & 3.594 & .000 \\
\hline N of Valid Cases & 10 & & & \\
\hline a. Not assuming the null hypothesis. & & & \\
\hline b. Using the asymptotic standard error assuming the null hypothesis. & \\
\hline
\end{tabular}

Step 7: The extracted model from the literature, which consists of 38 codes and 9 concepts, is presented in Figure 3.

\subsection{Delphi method for screening and adaption of the GHRM components}

In this phase, the Delphi method in two rounds is used to investigate GHRM codes with the nature of the construction industry's activities. The following sections provide more information about the two rounds of the Delphi method.

Round 1: In this round, those codes in which the sum of votes was less than 8.71 were eliminated from the list. As shown in Table 5, we see that in the first round, $\mathrm{C}_{14}, \mathrm{C}_{21}, \mathrm{C}_{24}, \mathrm{C}_{25}, \mathrm{C}_{32}, \mathrm{C}_{33}, \mathrm{C}_{34}, \mathrm{C}_{41}, \mathrm{C}_{45}, \mathrm{C}_{46}, \mathrm{C}_{71}, \mathrm{C}_{72}, \mathrm{C}_{73}$, and $\mathrm{C}_{93}$ codes were eliminated from the list due to their incompatibilities with the nature of the construction industry's activities. The second round was begun with the 24 remaining codes. 
Delphi method-first round: choosing the relevant codes with the construction industry.

\begin{tabular}{|c|c|c|c|c|c|c|c|c|c|c|c|c|c|c|c|c|}
\hline \multirow[t]{2}{*}{ Code } & \multicolumn{15}{|c|}{ Expert Number } & \multirow[t]{2}{*}{ Sum } \\
\hline & 1 & 2 & 3 & 4 & 5 & 6 & 7 & 8 & 9 & 10 & 11 & 12 & 13 & 14 & 15 & \\
\hline $\mathrm{C}_{11}$ & $\star$ & $\star$ & $\star$ & $\star$ & & $\star$ & $\star$ & $\star$ & & & $\star$ & $\star$ & $\star$ & & & 10 \\
\hline $\mathrm{C}_{12}$ & $\star$ & $\star$ & & $\star$ & & $\star$ & * & * & & $\star$ & * & & * & * & * & 11 \\
\hline $\mathrm{C}_{13}$ & * & & $\star$ & * & & & * & * & * & * & & * & & $\star$ & * & 10 \\
\hline $\mathrm{C}_{14}$ & & * & & & & * & & * & * & & & & & $\star$ & & 5 \\
\hline $\mathrm{C}_{15}$ & * & * & * & & & $*$ & * & & & * & * & * & & $\star$ & * & 10 \\
\hline $\mathrm{C}_{21}$ & * & * & * & & * & & * & & & & & & * & * & & 7 \\
\hline $\mathrm{C}_{22}$ & & * & * & * & * & $\star$ & & & & & * & * & * & * & * & 10 \\
\hline $\mathrm{C}_{23}$ & * & $\star$ & $\star$ & & * & $\star$ & & $\star$ & $\star$ & * & & $\star$ & * & $\star$ & $\star$ & 12 \\
\hline $\mathrm{C}_{24}$ & & & & * & $\star$ & & * & * & & & & & $\star$ & & $\star$ & 6 \\
\hline $\mathrm{C}_{25}$ & * & & * & * & & & & & * & * & & & & $\star$ & $\star$ & 7 \\
\hline $\mathrm{C}_{31}$ & * & * & * & & & & & * & * & * & * & * & $\star$ & & $\star$ & 10 \\
\hline $\mathrm{C}_{32}$ & * & * & & & $\star$ & & & * & * & * & & & & & & 6 \\
\hline $\mathrm{C}_{33}$ & & & * & & & * & * & & & & & & & & & 3 \\
\hline $\mathrm{C}_{34}$ & & * & & & & * & & * & * & & & & & * & & 5 \\
\hline $\mathrm{C}_{35}$ & & & $\star$ & $\star$ & & * & & * & * & & * & $\star$ & * & * & * & 10 \\
\hline $\mathrm{C}_{41}$ & * & & & & & & & * & * & & * & * & * & $\star$ & & 7 \\
\hline $\mathrm{C}_{42}$ & & * & & $\star$ & * & * & & * & * & & * & & * & * & * & 10 \\
\hline $\mathrm{C}_{43}$ & * & & $\star$ & & $*$ & & * & * & & * & * & * & * & $\star$ & * & 11 \\
\hline $\mathrm{C}_{44}$ & * & * & $\star$ & * & * & & * & * & * & * & * & * & * & * & & 13 \\
\hline $\mathrm{C}_{45}$ & * & & * & * & & & & & & & & $\star$ & $\star$ & $\star$ & & 6 \\
\hline $\mathrm{C}_{46}$ & & * & & * & * & * & & & & & & & & & * & 5 \\
\hline $\mathrm{C}_{51}$ & & * & $\star$ & * & * & * & * & * & * & & * & * & * & & $\star$ & 12 \\
\hline $\mathrm{C}_{52}$ & * & * & $\star$ & * & * & & * & * & * & * & & * & * & & & 11 \\
\hline $\mathrm{C}_{53}$ & $\star$ & * & & & * & & * & * & * & * & * & & * & * & * & 11 \\
\hline $\mathrm{C}_{61}$ & * & & * & * & & $\star$ & & * & * & $\star$ & * & * & & * & & 10 \\
\hline $\mathrm{C}_{62}$ & * & * & $\star$ & $\star$ & * & $\star$ & & $\star$ & $\star$ & & $\star$ & * & * & $\star$ & * & 13 \\
\hline $\mathrm{C}_{63}$ & * & * & $\star$ & $\star$ & & & & * & $\star$ & * & & * & * & & * & 10 \\
\hline $\mathrm{C}_{64}$ & * & * & & $\star$ & & & * & $\star$ & * & * & $\star$ & & $\star$ & $\star$ & $\star$ & 11 \\
\hline$C_{65}$ & * & * & $\star$ & $\star$ & * & $\star$ & $\star$ & * & $\star$ & & & & $\star$ & $\star$ & * & 12 \\
\hline $\mathrm{C}_{71}$ & & & & * & & $\star$ & & & & * & & & & & * & 4 \\
\hline $\mathrm{C}_{72}$ & & & & & & & * & $\star$ & & & & $\star$ & * & & $\star$ & 5 \\
\hline $\mathrm{C}_{73}$ & & & & $\star$ & * & & * & $\star$ & $\star$ & * & & & & & & 6 \\
\hline $\mathrm{C}_{81}$ & * & & * & * & & * & & * & $\star$ & * & $\star$ & $\star$ & & & & 9 \\
\hline $\mathrm{C}_{82}$ & * & & & & * & * & & * & * & & $\star$ & * & $\star$ & $\star$ & & 9 \\
\hline $\mathrm{C}_{83}$ & * & * & * & * & & $\star$ & & * & * & * & & $\star$ & * & & & 10 \\
\hline
\end{tabular}




\begin{tabular}{|c|c|c|c|c|c|c|c|c|c|c|c|c|c|c|c|c|}
\hline \multirow[t]{2}{*}{ Code } & \multicolumn{15}{|c|}{ Expert Number } & \multirow[t]{2}{*}{ Sum } \\
\hline & 1 & 2 & 3 & 4 & 5 & 6 & 7 & 8 & 9 & 10 & 11 & 12 & 13 & 14 & 15 & \\
\hline $\mathrm{C}_{91}$ & * & * & & * & & & * & * & * & * & * & & * & * & * & 11 \\
\hline $\mathrm{C}_{92}$ & * & * & * & * & * & * & * & * & * & & & & & * & & 10 \\
\hline $\mathrm{C}_{93}$ & & & & & & * & & & & & & & & * & * & 3 \\
\hline \multicolumn{17}{|c|}{ Average $=8.71$} \\
\hline
\end{tabular}

Round 2: In the second round, it was asked from the experts to specify the degree of necessity and importance of the 24 codes which may lead to achieving the GHRM purposes and then lead to sustainable environmental performance. Table 6 shows the 5 points Likert scale with corresponding verbs. Then, the completed questionnaire from each expert is collected, and the results are presented in Table 7. The second round aimed to identify the important key codes in which the experts had a minor disagreement. Therefore, we used the coefficient of variation (CV), and the CV among experts' votes was calculated. Finally, the codes whose CV was more than the average of the total CVs (number 0.1921) were eliminated. In the final step, 3 codes that there was a major disagreement among the experts were eliminated, and further analysis was performed with 21 remaining codes.

Table 6

Delphi method- second round: the degree of necessity and corresponding numerical amount.

\begin{tabular}{|llllll|}
\hline Numerical value & $\mathbf{1}$ & $\mathbf{2}$ & $\mathbf{3}$ & $\mathbf{4}$ & $\mathbf{5}$ \\
\hline Necessity scale & Unnecessary & Low necessary & Moderately necessary & Necessary & Very necessary \\
\hline
\end{tabular}


Table 7

Delphi method-second round: experts' consensus and calculating CV.

\begin{tabular}{|c|c|c|c|c|c|c|c|c|c|c|c|c|c|c|c|c|}
\hline \multirow[t]{2}{*}{ Code } & \multicolumn{15}{|c|}{ Expert Number } & \multirow[t]{2}{*}{$\mathrm{CV}$} \\
\hline & 1 & 2 & 3 & 4 & 5 & 6 & 7 & 8 & 9 & 10 & 11 & 12 & 13 & 14 & 15 & \\
\hline $\mathrm{C}_{11}$ & 4 & 4 & 4 & 3 & 4 & 4 & 3 & 4 & 5 & 4 & 4 & 3 & 4 & 5 & 4 & 0.15092 \\
\hline $\mathrm{C}_{12}$ & 4 & 3 & 4 & 3 & 4 & 3 & 3 & 4 & 5 & 4 & 4 & 3 & 4 & 5 & 4 & 0.177927 \\
\hline $\mathrm{C}_{13}$ & 3 & 3 & 4 & 5 & 5 & 5 & 4 & 4 & 4 & 3 & 4 & 4 & 4 & 3 & 4 & 0.178915 \\
\hline $\mathrm{C}_{15}$ & 3 & 2 & 2 & 3 & 2 & 3 & 2 & 2 & 2 & 2 & 2 & 2 & 2 & 2 & 2 & 0.1882 \\
\hline $\mathrm{C}_{22}$ & 3 & 4 & 5 & 5 & 4 & 5 & 5 & 4 & 3 & 4 & 5 & 5 & 5 & 5 & 4 & 0.167452 \\
\hline $\mathrm{C}_{23}$ & 4 & 4 & 5 & 5 & 4 & 5 & 5 & 4 & 3 & 4 & 5 & 5 & 5 & 5 & 5 & 0.141163 \\
\hline $\mathrm{C}_{31}$ & 5 & 4 & 4 & 5 & 4 & 4 & 4 & 4 & 3 & 4 & 5 & 5 & 5 & 3 & 5 & 0.164937 \\
\hline $\mathrm{C}_{35}$ & 4 & 2 & 5 & 5 & 4 & 5 & 4 & 5 & 4 & 4 & 5 & 5 & 4 & 5 & 4 & 0.188422 \\
\hline $\mathrm{C}_{42}$ & 4 & 4 & 4 & 3 & 3 & 4 & 4 & 4 & 3 & 5 & 4 & 3 & 4 & 3 & 4 & 0.159005 \\
\hline $\mathrm{C}_{43}$ & 5 & 4 & 4 & 4 & 4 & 3 & 4 & 4 & 3 & 4 & 5 & 3 & 3 & 4 & 5 & 0.178915 \\
\hline $\mathrm{C}_{44}$ & 4 & 4 & 5 & 3 & 4 & 3 & 5 & 4 & 4 & 4 & 4 & 5 & 5 & 5 & 3 & 0.179812 \\
\hline $\mathrm{C}_{51}$ & 5 & 4 & 4 & 5 & 5 & 5 & 4 & 4 & 3 & 4 & 5 & 3 & 5 & 4 & 5 & 0.167019 \\
\hline$C_{52}$ & 4 & 4 & 5 & 5 & 4 & 5 & 5 & 4 & 4 & 3 & 4 & 3 & 3 & 3 & 4 & 0.188982 \\
\hline $\mathrm{C}_{53}$ & 4 & 3 & 4 & 3 & 4 & 4 & 4 & 4 & 4 & 4 & 4 & 5 & 5 & 4 & 3 & 0.15092 \\
\hline $\mathrm{C}_{54}$ & 4 & 4 & 5 & 4 & 4 & 5 & 5 & 4 & 3 & 4 & 5 & 5 & 5 & 3 & 4 & 0.164937 \\
\hline $\mathrm{C}_{61}$ & 3 & 4 & 5 & 5 & 4 & 5 & 4 & 4 & 3 & 4 & 5 & 5 & 5 & 5 & 3 & 0.187221 \\
\hline $\mathrm{C}_{62}$ & 5 & 3 & 4 & 5 & 5 & 5 & 5 & 4 & 3 & 3 & 4 & 4 & 4 & 4 & 5 & 0.184428 \\
\hline $\mathrm{C}_{63}$ & 3 & 4 & 5 & 5 & 4 & 5 & 5 & 4 & 3 & 4 & 5 & 5 & 5 & 5 & 3 & 0.188422 \\
\hline $\mathrm{C}_{64}$ & 3 & 4 & 5 & 5 & 4 & 5 & 4 & 4 & 5 & 4 & 4 & 4 & 5 & 5 & 3 & 0.164937 \\
\hline $\mathrm{C}_{65}$ & 5 & 4 & 5 & 3 & 4 & 5 & 5 & 4 & 3 & 4 & 3 & 5 & 5 & 5 & 5 & 0.188422 \\
\hline $\mathrm{C}_{81}$ & 4 & 4 & 5 & 1 & 5 & 4 & 4 & 4 & 2 & 4 & 4 & 5 & 5 & 4 & 3 & 0.291068 \\
\hline $\mathrm{C}_{82}$ & 4 & 5 & 4 & 4 & 4 & 3 & 1 & 4 & 3 & 4 & 1 & 5 & 4 & 5 & 4 & 0.336662 \\
\hline $\mathrm{C}_{83}$ & 5 & 3 & 5 & 4 & 3 & 5 & 1 & 4 & 5 & 4 & 1 & 3 & 5 & 3 & 5 & 0.371522 \\
\hline $\mathrm{C}_{91}$ & 4 & 4 & 4 & 4 & 4 & 4 & 3 & 4 & 5 & 4 & 4 & 2 & 4 & 5 & 4 & 0.178915 \\
\hline $\mathrm{C}_{92}$ & 4 & 4 & 5 & 4 & 4 & 5 & 5 & 4 & 3 & 4 & 5 & 5 & 5 & 3 & 4 & 0.164937 \\
\hline
\end{tabular}

\subsection{Structural equation model to validate the proposed model}

1. Measurement model: As shown in Table 8, all CR values are greater than 0.7, and the values of AVE are more than 0.5. This indicates that the convergent validity of the questionnaire is acceptable. As shown in Table 9, all the values in the main diagonal are greater than the values at the bottom of the main diagonal. This indicates the divergent validity of the survey instrument is acceptable. 
Results of AVE and CR of constructs.

\begin{tabular}{|c|c|c|c|}
\hline Variable & Symbol & AVE & CR \\
\hline Top management actively support green practices & $\mathrm{C}_{11}$ & 0.810 & 0.895 \\
\hline Green organizational mission & $\mathrm{C}_{12}$ & 0.803 & 0.890 \\
\hline Green Organizational values & $\mathrm{C}_{13}$ & 0.772 & 0.871 \\
\hline Financial covering green activities & $\mathrm{C}_{15}$ & 0.790 & 0.883 \\
\hline Green recruitment process & $\mathrm{C}_{22}$ & 0.798 & 0.888 \\
\hline Green-based applicants evaluation & $\mathrm{C}_{23}$ & 0.829 & 0.907 \\
\hline Clear green vision & $\mathrm{C}_{31}$ & 0.790 & 0.882 \\
\hline Encouraging green involvement & $\mathrm{C}_{35}$ & 0.754 & 0.860 \\
\hline Clarifying green criteria in employee performance evaluation & $\mathrm{C}_{42}$ & 0.780 & 0.876 \\
\hline Green-based employee performance assessment & $\mathrm{C}_{43}$ & 0.654 & 0.789 \\
\hline Providing regular feedback for environmental performance & $\mathrm{C}_{44}$ & 0.862 & 0.926 \\
\hline Rewards for innovative environmental suggestions & $\mathrm{C}_{51}$ & 0.858 & 0.924 \\
\hline Rewards for innovative environmental performance & $\mathrm{C}_{52}$ & 0.786 & 0.880 \\
\hline Monetary and non-monetary rewards for environmental achievements & $\mathrm{C}_{53}$ & 0.820 & 0.901 \\
\hline Joint consultations for environmental issues problem solving & $\mathrm{C}_{61}$ & 0.790 & 0.883 \\
\hline Holding workshops to improve environmental behavior & $\mathrm{C}_{62}$ & 0.811 & 0.896 \\
\hline Providing conditions to exchange tacit knowledge & $\mathrm{C}_{63}$ & 0.903 & 0.949 \\
\hline Involving in formulating environmental strategy & $\mathrm{C}_{64}$ & 0.795 & 0.886 \\
\hline Using teamwork to increase environmental awareness & $\mathrm{C}_{65}$ & 0.820 & 0.901 \\
\hline Providing environmental training opportunities & $\mathrm{C}_{91}$ & 0.812 & 0.896 \\
\hline Giving the first priority to green training programs & $\mathrm{C}_{92}$ & 0.785 & 0.880 \\
\hline
\end{tabular}


Table 9

Matrix for comparing AVE square root with constructs' correlation coefficients.

\begin{tabular}{|c|c|c|c|c|c|c|c|c|c|c|c|c|c|c|c|c|}
\hline & $C_{11}$ & $\mathrm{C}_{12}$ & $\mathrm{C}_{13}$ & $\mathrm{C}_{15}$ & $\mathrm{C}_{22}$ & $c_{23}$ & $\mathrm{C}_{31}$ & $\mathrm{C}_{35}$ & $\mathrm{C}_{42}$ & $\mathrm{C}_{43}$ & $C_{44}$ & $C_{51}$ & $C_{52}$ & $C_{53}$ & $C_{61}$ & $C_{62}$ \\
\hline$C_{11}$ & 0.900 & & & & & & & & & & & & & & & \\
\hline$C_{12}$ & 0.463 & 0.896 & & & & & & & & & & & & & & \\
\hline $\mathrm{C}_{13}$ & 0.529 & 0.586 & 0.879 & & & & & & & & & & & & & \\
\hline$C_{15}$ & 0.041 & 0.080 & 0.011 & 0.889 & & & & & & & & & & & & \\
\hline$c_{22}$ & 0.046 & 0.075 & 0.077 & 0.611 & 0.894 & & & & & & & & & & & \\
\hline$c_{23}$ & 0.397 & 0.464 & 0.314 & 0.088 & 0.119 & 0.911 & & & & & & & & & & \\
\hline $\mathrm{C}_{31}$ & 0.212 & 0.302 & 0.265 & 0.080 & 0.127 & 0.568 & 0.889 & & & & & & & & & \\
\hline$c_{35}$ & 0.293 & 0.265 & 0.350 & -0.016 & 0.071 & 0.529 & 0.711 & 0.868 & & & & & & & & \\
\hline$C_{42}$ & -0.121 & -0.064 & -0.051 & 0.341 & 0.376 & -0.051 & -0.046 & -0.052 & 0.883 & & & & & & & \\
\hline$C_{43}$ & 0.050 & -0.044 & -0.067 & 0.337 & 0.455 & 0.038 & 0.000 & 0.036 & 0.341 & 0.809 & & & & & & \\
\hline$C_{44}$ & -0.023 & 0.043 & -0.013 & 0.482 & 0.564 & 0.110 & 0.036 & -0.024 & 0.452 & 0.487 & 0.928 & & & & & \\
\hline$C_{51}$ & 0.043 & 0.019 & 0.032 & 0.505 & 0.596 & 0.092 & 0.081 & 0.036 & 0.426 & 0.527 & 0.743 & 0.926 & & & & \\
\hline$C_{52}$ & -0.010 & 0.025 & 0.027 & 0.285 & 0.224 & 0.044 & 0.010 & -0.001 & 0.243 & 0.364 & 0.400 & 0.398 & 0.886 & & & \\
\hline $\mathrm{C}_{53}$ & -0.085 & -0.053 & -0.058 & 0.485 & 0.503 & -0.008 & 0.006 & -0.006 & 0.364 & 0.434 & 0.617 & 0.572 & 0.402 & 0.905 & & \\
\hline$C_{61}$ & 0.040 & 0.061 & -0.007 & 0.564 & 0.601 & 0.138 & 0.111 & -0.009 & 0.447 & 0.420 & 0.596 & 0.665 & 0.278 & 0.592 & 0.889 & \\
\hline$C_{62}$ & -0.123 & -0.124 & -0.131 & 0.104 & 0.136 & -0.035 & 0.005 & 0.001 & 0.107 & 0.341 & 0.132 & 0.200 & 0.272 & 0.197 & 0.216 & 0.901 \\
\hline $\mathrm{C}_{63}$ & 0.103 & 0.043 & 0.104 & 0.362 & 0.464 & 0.019 & 0.007 & 0.014 & 0.491 & 0.437 & 0.546 & 0.569 & 0.362 & 0.376 & 0.463 & 0.133 \\
\hline$C_{64}$ & -0.078 & -0.015 & -0.048 & 0.148 & 0.152 & -0.027 & 0.015 & 0.002 & 0.178 & 0.337 & 0.128 & 0.129 & 0.316 & 0.145 & 0.152 & 0.484 \\
\hline $\mathrm{C}_{65}$ & -0.113 & -0.117 & -0.175 & 0.232 & 0.204 & -0.084 & -0.039 & -0.080 & 0.146 & 0.417 & 0.244 & 0.229 & 0.345 & 0.281 & 0.249 & 0.714 \\
\hline$C_{91}$ & 0.100 & 0.059 & 0.085 & 0.486 & 0.591 & 0.099 & 0.048 & -0.003 & 0.396 & 0.459 & 0.634 & 0.662 & 0.254 & 0.519 & 0.587 & 0.087 \\
\hline $\mathrm{C}_{92}$ & 0.036 & 0.013 & 0.092 & 0.509 & 0.531 & 0.070 & 0.044 & 0.004 & 0.444 & 0.371 & 0.607 & 0.623 & 0.239 & 0.442 & 0.553 & 0.018 \\
\hline
\end{tabular}

In addition to the acceptable value of the Cronbach's alpha for this study, we used the factor loading in the PLS method to evaluate the reliability of the questionnaire. The results showed that the coefficients of factor loading among measures and corresponding constructs are more than 0.4 , indicating the reliability of the survey instrument is acceptable.

2. Structural model: After receiving acceptable results for the measurement of reliability and validity, the relationships among the latent variables are analyzed via the structural model. Figure 4 shows the coefficients among the latent variables.

As shown in Figure 4, t coefficients among two constructs including green organizational culture $\left(C_{1}\right)$ and green involvement $\left(C_{3}\right)$ are less than 1.96 , which indicate no significant relationship between them. Except for the two mentioned constructs, $t$ coefficients among the other first and second-ordered constructs are more than 1.96, indicating a significant relationship between these constructs. By eliminating the green organizational culture construct $\left(\mathrm{C}_{1}\right)$ and green education and development construct $\left(\mathrm{C}_{3}\right)$, the final GHRM model in the construction industry is presented in Figure 5.

\section{Discussion And Conclusions}

The originality of this paper lies in the presentation of a GHRM model for the construction industry that is the first GHRM model which is applied in the construction industry. This model indicates the contributing components in GHRM for the construction industry. To construct this model, an in-depth literature review is conducted and contributing components of GHRM were identified and the primary model of GHRM was presented. Then, using the Delphi method in two rounds, the GHRM components were adopted and customized with the construction industry. Finally, to validate the GHRM model the data were collected from the managers of the construction industry through the questionnaire and were analyzed using SEM and SmartPLS3 software. In the rest of the paper, we discuss theoretical contributions, managerial implications, as well as study limitations and some future directions.

\subsection{Theoretical contributions}


The findings indicated that among 9 main GHRM components extracted from literature, just 5 components including green recruitment and selection, green performance management, green- reward, green-based employee empowerment, and green training have statistically significant and positive relationships with GHRM. The findings imply that green recruitment is one of the basic and the most important components of GHRM that can influence the other components. By considering green criteria in recruitment can lead companies to environmentally sustainable performance through hiring employees who are aware of the environmental issues. This finding agrees with Masri and Jarron (2017), Zhang et al. (2019), and Yong et al. (2020).

The results of data analysis revealed that there is a significant and positive relationship between green performance management and GHRM. Clarifying green criteria in evaluating employees' performance and emphasizing green criteria in performance assessment can force employees to improve their environmental performance. Besides, providing regular feedback is one of the factors influencing continuous improvement in environmental performance. These findings are in line with Zaid et al. (2018), Masri and Jarron (2017), and Harvey et al. (2013). Green performance and appraisal can guide employees to achieve the desired environmental performance (Ahmad, 2015). Providing regular feedback will enhance employees' environmental knowledge and skills that have a significant effect on improving environmental performance (Arulrajah et al., 2016; Jackson et al., 2011).

The finding implies that there is a significant and positive relationship between green reward and GHRM. Among the other GHRM practices reward is often considered as the most important practice that can bring the company's interest and employee's interest closer together (Jackson et al., 2011). In some cases, just monetary and non-monetary rewards can motivate employees to improve their environmental performance (Danish, and Usman, 2010). This finding of the present study supports Renwick, Redman, and Maguire's (2013) finding of the effect of reward on increasing employees' willingness to improve their environmental performance. To encourage employees to participate in the company's environmental strategies, managers not only should consider rewards for innovative environmental performance but also they have to consider rewards for innovative environmental suggestions (Masri and Jarron, 2017).

The finding of the present study indicated that green-based employee empowerment is one of the main components of GHRM in the construction industry. This finding agrees with Daily et al. (2012) and Masri and Jarron (2017). Some practices such as teamwork by increasing the employees' awareness about environmental issues can empower them and improve their environmental performance (Boiral, 2009; Masri and Jarron, 2017; Jabbour, 2011). One way to empower employees regarded environmental issues is to involve them in formulating corporate environmental strategies (Yong et al., 2020). Holding workshops can increase employees' environmental performance. Also, encouraging employees to participate in the company's greening programs can help to hear the voice of employees and may make a big improvement in the company's environmental performance.

The data analysis results indicated a significant and positive relationship between green training and GHRM. Green training can provide the necessary knowledge for employees about environmental issues (Jabbour, et al., 2010). Yong et al. (2020) in a study on 112 Malaysian manufacturing companies found out a significant and positive relationship between green training and employees' environmental performance. Green training has a positive impact on employees' environmental knowledge and performance and can be used when the companies want to change employees' attitudes and increase awareness about environmental issues (Sammalisto and Brorson, 2008). In the present study, the knowledge of employees about environmental issues in construction companies was at a low level. There is a need to provide a training opportunity for employees and give the priority to green training programs as the first and fundamental step to achieve environmentally sustainable performance.

\subsection{Managerial implications}

Aside from the theoretical contribution of the present study, there are several managerial implications that can help the practitioners to make effective environmental policy in order to reach environmentally sustainable performance in their companies. This section provides the key points for managers of construction companies. According to the managers of Iranian construction companies, there are not enough knowledge and awareness about environmental issues in the construction industry. In other words, when the construction company managers want to implement GHRM practices they do not know how and from where they should start to implement GHRM practices. From a practical perspective, the model presented in this study can be used as a roadmap for the managers of construction companies to increase their companies' environmentally sustainable performance. The final proposed model indicates the effective factors of GHRM practices including green recruitment and selection, green performance management, green- reward, green-based employee empowerment, and green training in the construction industry. Therefore, according to the presented model managers can decide about investing in which areas to gain maximum results of implementing GHRM practices.

The result of the present study indicated that "green reward" is the most effective factor of GHRM. Therefore, it is proposed to the managers of construction companies to motivate employees to improve their green performance or provide innovative environmental suggestions. According to the model, "green performance management" was identified as the second effective factor of GHRM. Therefore, the managers of Iranian construction companies should improve employees' green performance through determining green criteria in performance assessment and giving regular feedback for their environmental performance. The construction industry in Iran is reported to have poor knowledge and awareness about environmental issues, therefore, the government should give the first priority to environmental issues in the construction industry through providing infrastructures and opportunities for green training. Inviting some experts from leading countries in order to teach environmental issues to Iranian employees is proposed.

\subsection{Limitations and future directions}

Although the main goal of this paper was addressed as expected, and the first GHRM model for the construction industry was presented, there are some limitations. For instance, the main limitation of the present study, which is the reason for the next limitation, is the use of cross-sectional data to evaluate and test the proposed model. The data of the present study were collected over a period of time, therefore, it was not possible to access the objective data. For example, in the present study, there was no longitudinal data to evaluate the outputs of green training or green reward in construction companies. Because so far, no evaluation has been done on the results of holding green training and the data only reflects the opinion of managers in this regard. Therefore, it is suggested that in future research, if possible, longitudinal and multi-sectional data be used to test the proposed model. 
Since the data were collected from 33 Iranian construction companies, the results of this study may not be generalizable to other industries. Therefore, a cross-country study may enhance the generalizability of the findings and may affect the results. Besides, we suggest future research test the proposed model by collecting data from other industries and comparing the results with the results of the present study. Also, in future research, the effect of GHRM components on sustainable performance can be examined and using importance-performance map analysis, the existing gaps between current and ideal situations of each of the GHRM components can be identified. Then, according to the location of each component in the importance-performance matrix, some practical strategies to eliminate or reduce gaps can be proposed. Finally, in future research in order to weigh and prioritize the contributing factors of GHRM multi-criteria decision-making methods such as AHP, and BWM can be used.

\subsection{Conclusions}

In developing countries such as Iran, housing is one of the most important concerns of people and governments. Therefore, the construction industry contributes to providing fair conditions for people to have housing as one of their basic needs. On the other hand, the lack of familiarity of construction industry managers with environmental issues led the authors to examine the current state of the construction industry in terms of environmental issues and provide some practical solutions to achieve the ideal conditions. Given the prominent role of human resources in this industry, in the present study, presenting a model of GHRM for the construction industry was considered.

In this study, a hybrid approach including three phases was used to design and test a GHRM model in the construction industry. Using the meta-synthesis approach in the first phase, an in-depth and extensive review was conducted in the related GHRM literature. As a result, a three-level model of green supply chain management concepts and codes including 9 components and 38 indicators was designed as the initial model. In the second phase, to adapt and customize the initial model with the nature of the activity of the studied industry, the Delphi method was used. During two rounds of repetition in the Delphi method, a total of 2 concepts and 17 codes were removed from the initial model process and the third phase began with 7 concepts and 21 remaining codes. Using the SEM method in this phase, a three-level model of GHRM in the construction industry is developed which includes 5 main components. It implies that HR managers in construction companies should focus on green recruitment and selection, green performance management, green- reward, green-based employee empowerment, and green training to achieve sustainability.

Despite the limitations, this study as the first study that considered GHRM in the construction industry can have a significant role in the sustainability of Iranian construction companies. Furthermore, many of the findings in the present study throw up interesting contradictions to the existing literature. For example, the finding of this study indicated that green organizational culture has no significant role in GHRM in the construction industry. Thus, there is a need for future study in this industry in other developing or developed countries and compare the findings with the present study's findings to resolve barriers to sustainable construction as much as possible (Pham et al., 2020b).

\section{Declarations}

Author contribution Saeid Sadeghi Darvazeh: Formulating idea, Writing, Methodology, Investigation.

Farzaneh Mansoori Mooseloo: Methodology, Writing, Original draft preparation.

Samira Aeini: Validation, Literature review, Software.

Hadi Rezaei Vandchali: Reviewing, Supervision, Investigation.

Erfan Babaee Tirkolaee: Editing, Supervision, Investigation.

Funding There is no funding source.

Data availability Not applicable.

Ethics approval Not applicable.

Consent to participate Not applicable.

Consent for publication Not applicable.

Conflict of Interest The authors declare no competing interests

\section{References}

1. Ahmad, S. (2015). Green human resource management: Policies and practices. Cogent business and management, 2(1), 1030817. https://doi.org/10.1080/23311975.2015.1030817.

2. Al-Ghazali, B. M., and Afsar, B. (2021). Retracted: Green human resource management and employees' green creativity: The roles of green behavioral intention and individual green values. Corporate Social Responsibility and Environmental Management, 28(1), 536-536. https://doi.org/10.1002/csr.1987.

3. Ansari, N. Y., Farrukh, M., and Raza, A. (2021). Green human resource management and employees pro-environmental behaviours: Examining the underlying mechanism. Corporate Social Responsibility and Environmental Management, 28(1), 229-238. https://doi.0.1002/csr.2044.

4. Arulrajah, A. A., Opatha, H. H. D. N. P., and Nawaratne, N. N. J. (2016). Green human resource management practices: A review. Sri Lankan Journal of Human Resource Management, 5(1), 1-16. http://dx.doi.org/10.4038/sljhrm.v5i1.5624.

Page $14 / 19$ 
5. Boiral, O. (2009). Greening the corporation through organizational citizenship behaviors. Journal of Business Ethics, 87(2), $221-236$.

https://doi.org/10.1007/s10551-008-9881-2.

6. Bombiak, E., and Marciniuk-Kluska, A. (2018). Green human resource management as a tool for the sustainable development of enterprises: Polish young company experience. Sustainability, 10(6), 1739. https://doi.org/10.3390/su10061739.

7. Chams, N., and García-Blandón, J. (2019). On the importance of sustainable human resource management for the adoption of sustainable development goals. Resources, Conservation and Recycling, 141, 109-122. https://doi.org/10.1016/j.resconrec.2018.10.006.

8. Chang, C.-H. (2015). Proactive and reactive corporate social responsibility: antecedent and consequence. Management Decision, 53(2), $451-468$. https://doi.org/10.1108/MD-02-2014-0060.

9. Daily, B. F., and Huang, S. C. (2001). Achieving sustainability through attention to human resource factors in environmental management. International Journal of operations and production management, 21(12), 1539-1552. https://doi.org/10.1108/01443570110410892.

10. Daily, B. F., Bishop, J. W., and Massoud, J. A. (2012). The role of training and empowerment in environmental performance. International Journal of operations and production management, 32(5), 631-647. https://doi.org/10.1108/01443571211226524.

11. Danish, R. Q., and Usman, A. (2010). Impact of reward and recognition on job satisfaction and motivation: An empirical study from Pakistan. International Journal of Business and Management, 5(2), 159-167. http://dx.doi.org/10.5539/ijbm.v5n2p159.

12. DuBois, C. L., and Dubois, D. A. (2012). Strategic HRM as social design for environmental sustainability in organization. Human Resource Management, 51(6), 799-826. https://doi.org/10.1002/hrm.21504.

13. Dumont, J., Shen, J., and Deng, X. (2017). Effects of green HRM practices on employee workplace green behavior: The role of psychological green climate and employee green values. Human resource management, 56(4), 613-627. https://doi.org/10.1002/hrm.21792.

14. Dutta, D. (2012). Greening people: A strategic dimension. ZENITH International Journal of Business Economics and Management Research, 2(2), $143-148$. https://ssrn.com/abstract=2382034.

15. Ehnert, I. (2009). Sustainability and human resource management: reasoning and applications on corporate websites. European Journal of International Management, 3(4), 419-438. https://doi.org/10.1504/EJIM.2009.028848.

16. Ellinger, A.E., Ellinger, A.D. (2014). Leveraging human resource development expertise to improve supply chain managers' skills and competencies. European Journal of Training and Development, 38 (12), 118-135. https://doi.org/10.1108/EJTD-09-2013-0093.

17. Esposito Vinzi, V., Chin, W. W., Henseler, J., and Wang, H. (2010). Handbook of partial least squares: Concepts, methods and applications. Heidelberg, Dordrecht, London, New York: Springer. https://doi.org/10.1007/978-3-540-32827-8.

18. Gardas, B. B., Raut, R. D., and Narkhede, B. (2019). Identifying critical success factors to facilitate reusable plastic packaging towards sustainable supply chain management. Journal of environmental management, 236, 81-92. https://doi.org/10.1016/j.jenvman.2019.01.113.

19. Gholami, H., Rezaei, G., Saman, M. Z. M., Sharif, S., and Zakuan, N. (2016). State-of-the-art Green HRM System: Sustainability in the sports center in Malaysia using a multi-methods approach and opportunities for future research. Journal of Cleaner Production, 124, 142-163. ttps://doi.org/10.1016/j.jclepro.2016.02.105.

20. Ghouri, A. M., Mani, V., Khan, M. R., Khan, N. R., and Srivastava, A. P. (2020). Enhancing business performance through green human resource management practices: an empirical evidence from Malaysian manufacturing industry. International Journal of productivity and Performance Management, 69(8), 1585-1607. https://doi.org/10.1108/IJPPM-11-2019-0520.

21. Gilal, F. G., Ashraf, Z., Gilal, N. G., Gilal, R. G., and Channa, N. A. (2019). Promoting environmental performance through green human resource management practices in higher education institutions: A moderated mediation model. Corporate Social Responsibility and Environmental Management, 26(6), 1579-1590. https://doi.org/10.1002/csr.1835.

22. Govindan, K., Khodaverdi, R., and Jafarian, A. (2013). A fuzzy multi criteria approach for measuring sustainability performance of a supplier based on triple bottom line approach. Journal of Cleaner Production, 47, 345-354. https://doi.org/10.1016/j.jclepro.2012.04.014.

23. Gupta, S., and Kumar, V. (2013). Sustainability as corporate culture of a brand for superior performance. Journal of World Business, 48(3), 311-320. https://doi.org/10.1016/j.jwb.2012.07.015.

24. Hair, J. F., Hult, G. T. M., Ringle, C. M., Sarstedt, M., and Thiele, K. O. (2017). Mirror, mirror on the wall: a comparative evaluation of composite-based structural equation modeling methods. Journal of the Academy of Marketing Science, 45(5), 616-632. https://doi.org/10.1007/s11747-017-0517-x.

25. Harvey, G., Williams, K., and Probert, J. (2013). Greening the airline pilot: HRM and the green performance of airlines in the UK. The International Journal of Human Resource Management, 24(1), 152-166. https://doi.org/10.1080/09585192.2012.669783.

26. Jabbour, C. J. C. (2013). Environmental training in organisations: From a literature review to a framework for future research. Resources, Conservation and Recycling, 74, 144-155. https://doi.org/10.1016/j.resconrec.2012.12.017.

27. Jabbour, C. J. C., and de Sousa Jabbour, A. B. L. (2016). Green human resource management and green supply chain management: Linking two emerging agendas. Journal of Cleaner Production, 112, 1824-1833. https://doi.org/10.1016/j.jclepro.2015.01.052.

28. Jabbour, C. J. C., and Santos, F. C. A. (2008). The central role of human resource management in the search for sustainable organizations. The International Journal of Human Resource Management, 19(12), 2133-2154. https://doi.org/10.1080/09585190802479389.

29. Jabbour, C. J. C., Santos, F. C. A., and Nagano, M. S. (2010). Contributions of HRM throughout the stages of environmental management: methodological triangulation applied to companies in Brazil. The International Journal of Human Resource Management, 21(7), $1049-1089$.

https://doi.org/10.1080/09585191003783512.

30. Jackson, S. E., and Seo, J. (2010). The greening of strategic HRM scholarship. Organization Management Journal, 7(4), $278-290$.

https://doi.org/10.1057/omj.2010.37.

Page $15 / 19$ 
31. Jackson, S. E., Renwick, D. W., Jabbour, C. J., and Muller-Camen, M. (2011). State-of-the-art and future directions for green human resource management: Introduction to the special issue. German Journal of Human Resource Management, 25(2), 99-116. https://doi.org/10.1177/239700221102500203.

32. Jose Chiappetta Jabbour, C. (2011), "How green are HRM practices, organizational culture, learning and teamwork? A Brazilian study", Industrial and Commercial Training, 43(2), pp. 98-105. https://doi.org/10.1108/00197851111108926.

33. Kawakami, T., Barczak, G., and Durmuşoğlu, S. S. (2015). Information technology tools in new product development: The impact of complementary resources. Journal of Product Innovation Management, 32(4), 622-635. https://doi.org/10.1111/jpim.12244.

34. Kim, Y. J., Kim, W. G., Choi, H. M., and Phetvaroon, K. (2019). The effect of green human resource management on hotel employees' eco-friendly behavior and environmental performance. International Journal of Hospitality Management, 76, 83-93. https://doi.org/10.1016/j.ijhm.2018.04.007.

35. Lin, T. C., and Huang, C. C. (2009). Understanding social loafing in knowledge contribution from the perspectives of justice and trust. Expert Systems with Applications, 36(3), 6156-6163. https://doi.org/10.1016/j.eswa.2008.07.014.

36. Lo, S. H., Peters, G. J. Y., and Kok, G. (2012). A review of determinants of and interventions for proenvironmental behaviors in organizations. Journal of Applied Social Psychology, 42(12), 2933-2967. https://doi.org/10.1111/j.1559-1816.2012.00969.x.

37. Longoni, A., Golini, R., and Cagliano, R. (2014). The role of new forms of work organization in developing sustainability strategies in operations. International Journal of Production Economics, 147, 147-160. https://doi.org/10.1016/j.jpe.2013.09.009.

38. Luciano, A., Cutaia, L., Cioffi, F., \& Sinibaldi, C. (2021). Demolition and construction recycling unified management: The DECORUM platform for improvement of resource efficiency in the construction sector. Environmental Science and Pollution Research, 28(19), $24558-24569$. https://doi.org/10.1007/s11356-020-09513-6.

39. Marshall, D., McCarthy, L., McGrath, P. and Claudy, M. (2015). Going above and beyond: how sustainability culture and entrepreneurial orientation drive social sustainability supply chain practice adoption. Supply Chain Management, 20(4), 434-454. https://doi.org/10.1108/SCM-08-2014-0267.

40. Masri, H. A., and Jaaron, A. A. (2017). Assessing green human resources management practices in Palestinian manufacturing context: An empirical study. Journal of Cleaner Production, 143, 474-489. https://doi.org/10.1016/j.jclepro.2016.12.087.

41. Masri, H. A., and Jaaron, A. A. (2017). Assessing green human resources management practices in Palestinian manufacturing context: An empirical study. Journal of Cleaner Production, 143, 474-489. https://doi.org/10.1016/j.jclepro.2016.12.087.

42. May, D. R., and Flannery, B. L. (1995). Cutting waste with employee involvement teams. Business Horizons, 38(5), 28-39. https://doi.org/10.1016/00076813(95)90033-0.

43. Mishra, P. (2017). Green human resource management. International Journal of Organizational Analysis, 25(5), 762-788. https://doi.org/10.1108/IJOA11-2016-1079.

44. Mousa, S. K., and Othman, M. (2020). The impact of green human resource management practices on sustainable performance in healthcare organisations: A conceptual framework. Journal of Cleaner Production, 243, 118595. https://doi.org/10.1016/j.jclepro.2019.118595.

45. Nejati, M., Rabiei, S., and Jabbour, C. J. C. (2017). Envisioning the invisible: Understanding the synergy between green human resource management and green supply chain management in manufacturing firms in Iran in light of the moderating effect of employees' resistance to change. Journal of Cleaner Production, 168, 163-172. https://doi.org/10.1016/j.jclepro.2017.08.213.

46. Nisar, Q. A., Haider, S., Ali, F., Jamshed, S., Ryu, K., and Gill, S. S. (2021). Green Human Resource Management Practices and Environmental Performance in Malaysian Green Hotels: The role of Green Intellectual Capital and Pro-Environmental Behavior. Journal of Cleaner Production, 127504. https://doi.org/10.1016/j.jclepro.2021.127504.

47. Nisar, Q. A., Haider, S., Ali, F., Jamshed, S., Ryu, K., and Gill, S. S. (2021). Green human resource management practices and environmental performance in Malaysian green hotels: The role of green intellectual capital and pro-environmental behavior. Journal of Cleaner Production, $311,127504$. https://doi.org/10.1016/j.jclepro.2021.127504.

48. North, K. (1997). Environmental business management: an introduction (Vol. 30). International Labour Organization.

49. Oh, D. S., Phillips, F., Park, S., and Lee, E. (2016). Innovation ecosystems: A critical examination. Technovation, 54, 1-6. https://doi.org/10.1016/j.technovation.2016.02.004.

50. Opatha, H. H. D. N. P. (2013), Green Human Resource Management: A Simplified Introduction, HR Dialogue, Department of HRM, Faculty of Management Studies and Commerce, University of Sri Jayewardenepura, 22-41. URI: http://dr.lib.sjp.ac.lk/handle/123456789/3734.

51. Opatha, H. H. P., and Arulrajah, A. A. (2014). Green human resource management: Simplified general reflections. International Business Research, 7(8), 101-112. DOI: 10.5539/ibr.v7n8p101.

52. Paille, P., Chen, Y., Boiral, O., and Jin, J. (2014). The impact of human resource manage- ment on environmental performance: an employee-level study. Journal of Business Ethics, 121(3), 451-466. https://doi.org/10.1007/s10551-013-1732-0.

53. Pham, N. T., Thanh, T. V., Tučková, Z., and Thuy, V. T. N. (2020a). The role of green human resource management in driving hotel's environmental performance: Interaction and mediation analysis. International Journal of Hospitality Management, 88, 102392. https://doi.org/10.1016/j.ijhm.2019.102392.

54. Pham, H., Kim, S. Y., \& Luu, T. V. (2020b). Managerial perceptions on barriers to sustainable construction in developing countries: Vietnam case. Environment, Development and Sustainability, 22(4), 2979-3003. https://doi.org/10.1007/s10668-019-00331-6.

55. Phipps, S. T., Prieto, L. C., and Ndinguri, E. N. (2013). Understanding the impact of employee involvement on organizational productivity: The moderating role of organizational commitment. Journal of Organizational Culture, Communications and Conflict, 17(2), 107.

56. Pinzone, M., Guerci, M., Lettieri, E., and Redman, T.(2016). Progressing in the change journey towards sustainability in healthcare: the role of 'Green' HRM. Journal of Cleaner Production, 122, 201-211. https://doi.org/10.1016/j.jclepro.2016.02.031.

Page $16 / 19$ 
57. Pohjola, M. (2001). Information technology, productivity, and economic growth: International evidence and implications for economic development. Oxford University Press.

58. Raut, R.D., Gardas, B., Luthra, S., Narkhede, B. and Kumar Mangla, S. (2020). Analysing green human resource management indicators of automotive service sector", International Journal of Manpower, Vol. 41 No. 7, pp. 925-944. https://doi.org/10.1108/IJM-09-2019-0435.

59. Rayner, J., and Morgan, D. (2018). An empirical study of 'green'workplace behaviours: ability, motivation and opportunity. Asia Pacific Journal of Human Resources, 56(1), 56-78. https://doi.org/10.1111/1744-7941.12151.

60. Renwick, D. W., Redman, T., and Maguire, S. (2013). Green human resource management: A review and research agenda. International Journal of Management Reviews, 15(1), 1-14. https://doi.org/10.1111/j.1468-2370.2011.00328.x.

61. Renwick, D., Jabbour, C.J.C., Muller-Camen, M., Redman, T., and Wilkinson, A. (2012). Introduction to the Green (environmental) human resource management special issue. The International Journal of Human Resource Management, 23(16), 3498-3499.

62. Revill, C. (2000). The Greening of Personnel. Human Resource Management an Assessment, International Journal of Applied HRM, 1(3), 1-30.

63. Roscoe, S., Subramanian, N., Jabbour, C. J., and Chong, T. (2019). Green human resource management and the enablers of green organisational culture: Enhancing a firm's environmental performance for sustainable development. Business Strategy and the Environment, 28(5), 737-749. https://doi.org/10.1002/bse.2277.

64. Rothenberg, S. (2003). Knowledge content and worker participation in environmental management at NUMMI. Journal of Management Studies, 40(7), 1783-1802. https://doi.org/10.1111/1467-6486.00400.

65. Sammalisto, K., and Brorson, T. (2008). Training and communication in the implementation of environmental management systems (ISO 14001): a case study at the University of Gävle, Sweden. Journal of Cleaner Production, 16(3), 299-309. https://doi.org/10.1016/j.jclepro.2006.07.029.

66. Sarkar, A., Qian, L., \& Peau, A. K. (2020). Overview of green business practices within the Bangladeshi RMG industry: competitiveness and sustainable development perspective. Environmental Science and Pollution Research, 27(18), 22888-22901. https://doi.org/10.1007/s11356-020-08816-y.

67. Sarkis, J. (2012). A boundaries and flows perspective of green supply chain management. Supply chain management: an international journal, 17(2), 202216. https://doi.org/10.1108/13598541211212924.

68. Siddique, C. M. (2004). Job analysis: a strategic human resource management practice. The International Journal of Human Resource Management, 15(1), 219-244. https://doi.org/10.1080/0958519032000157438.

69. Singh, S. K., Del Giudice, M., Chierici, R., and Graziano, D. (2020). Green innovation and environmental performance: The role of green transformational leadership and green human resource management. Technological Forecasting and Social Change, 150, 119762.

https://doi.org/10.1016/j.techfore.2019.119762.

70. Siyambalapitiya, J., Zhang, X., and Liu, X. (2018). Green human resource management: A proposed model in the context of Sri Lanka's tourism industry. Journal of Cleaner Production, 201, 542-555. https://doi.org/10.1016/j.jclepro.2018.07.305.

71. Tam, C. M., Tam, V. W., and Tsui, W. S. (2004). Green construction assessment for environmental management in the construction industry of Hong Kong. International Journal of Project Management, 22(7), 563-571. https://doi.org/10.1016/j.ijproman.2004.03.001.

72. Tang, G., Chen, Y., Jiang, Y., Paille, P., and Jia, J. (2018). Green human resource management practices: scale development and validity. Asia Pacific Journal of Human Resources, 56(1), 31-55. https://doi.org/10.1111/1744-7941.12147.

73. Tariq, S., Jan, F. A., and Ahmad, M. S. (2016). Green employee empowerment: a systematic literature review on state-of-art in green human resource management. Quality and Quantity, 50(1), 237-269. https://doi.org/10.1007/s11135-014-0146-0.

74. Tavana, M., Izadikhah, M., Saen, R. F., \& Zare, R. (2021). An integrated data envelopment analysis and life cycle assessment method for performance measurement in green construction management. Environmental Science and Pollution Research, 28(1), 664-682. https://doi.org/10.1007/s11356-02010353-7.

75. Teixeira, A. A., Jabbour, C. J. C., and de Sousa Jabbour, A. B. L. (2012). Relationship between green management and environmental training in companies located in Brazil: A theoretical framework and case studies. International Journal of Production Economics, 140(1), 318-329.

https://doi.org/10.1016/j.ijpe.2012.01.009.

76. Vijai, C., and Joyce, M. D. (2021). A Theoretical Study on Green Human Resource Management (Ghrm): An Innovative Practice for Organizational Sustainability. European Journal of Molecular and Clinical Medicine, 7(11), 3007-3013.

77. Wagner, M. (2011). Environmental management activities and sustainable HRM in German manufacturing firms-incidence, determinants, and outcomes. German Journal of Human Resource Management, 25(2), 157-177. https://doi.org/10.1177/239700221102500206.

78. Walker, K., Ni, N., and Huo, W. (2014). Is the red dragon green? An examination of the antecedents and consequences of environmental proactivity in China. Journal of Business Ethics, 125(1), 27-43. https://doi.org/10.1007/s10551-013-1903-z.

79. Yin, S., and Li, B. (2019). Academic research institutes-construction enterprises linkages for the development of urban green building: Selecting management of green building technologies innovation partner. Sustainable Cities and Society, 48, 101555. https://doi.org/10.1016/j.scs.2019.101555.

80. Yong, J. Y., Yusliza, M. Y., and Fawehinmi, O. O. (2019). Green human resource management: A systematic literature review from 2007 to 2019. Benchmarking: An International Journal.

81. Yong, J. Y., Yusliza, M. Y., Ramayah, T., and Fawehinmi, O. (2019). Nexus between green intellectual capital and green human resource management. Journal of Cleaner Production, 215, 364-374. https://doi.org/10.1016/j.jclepro.2018.12.306.

82. Yong, J. Y., Yusliza, M. Y., Ramayah, T., Chiappetta Jabbour, C. J., Sehnem, S., and Mani, V. (2020). Pathways towards sustainability in manufacturing organizations: Empirical evidence on the role of green human resource management. Business Strategy and the Environment, 29(1), $212-228$.

https://doi.org/10.1002/bse.2359.

Page $17 / 19$ 
83. Yu, W., Chavez, R., Feng, M., Wong, C. Y., and Fynes, B. (2020). Green human resource management and environmental cooperation: An ability-motivationopportunity and contingency perspective. International Journal of Production Economics, 219, 224-235. https://doi.org/10.1016/j.ijpe.2019.06.013.

84. Zaid, A. A., Jaaron, A. A., and Bon, A. T. (2018). The impact of green human resource management and green supply chain management practices on sustainable performance: An empirical study. Journal of Cleaner Production, 204, 965-979. https://doi.org/10.1016/j.jclepro.2018.09.062.

85. Zaid, A. A., Jaaron, A. A., and Bon, A. T. (2018). The impact of green human resource management and green supply chain management practices on sustainable performance: An empirical study. Journal of cleaner production, 204, 965-979.

86. Zhang, Y., Luo, Y., Zhang, X., and Zhao, J. (2019). How green human resource management can promote green employee behavior in China: A technology acceptance model perspective. Sustainability, 11(19), 5408. https://doi.org/10.3390/su11195408.

\section{Figures}

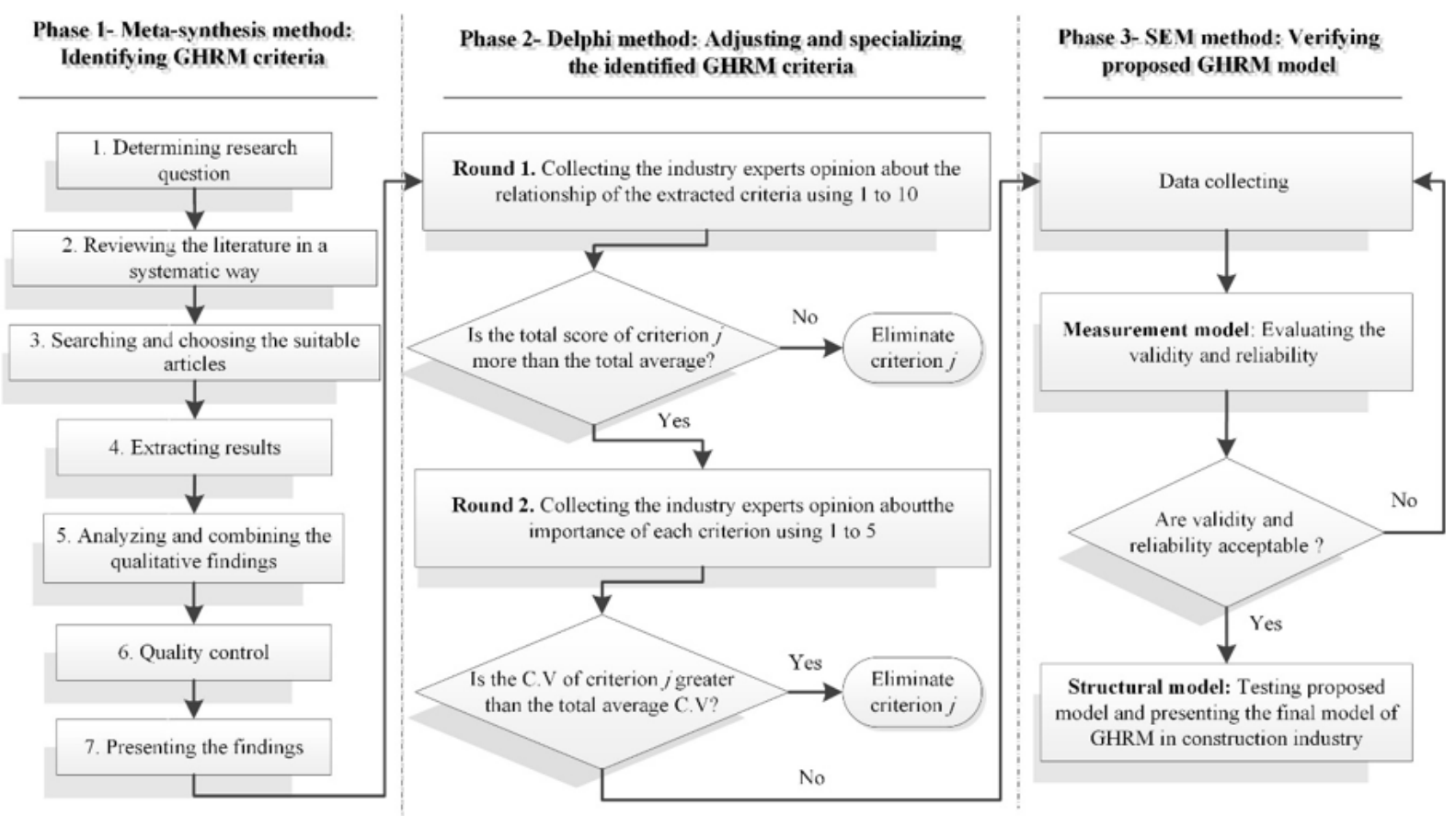

\section{Figure 1}

General framework of executing the research.

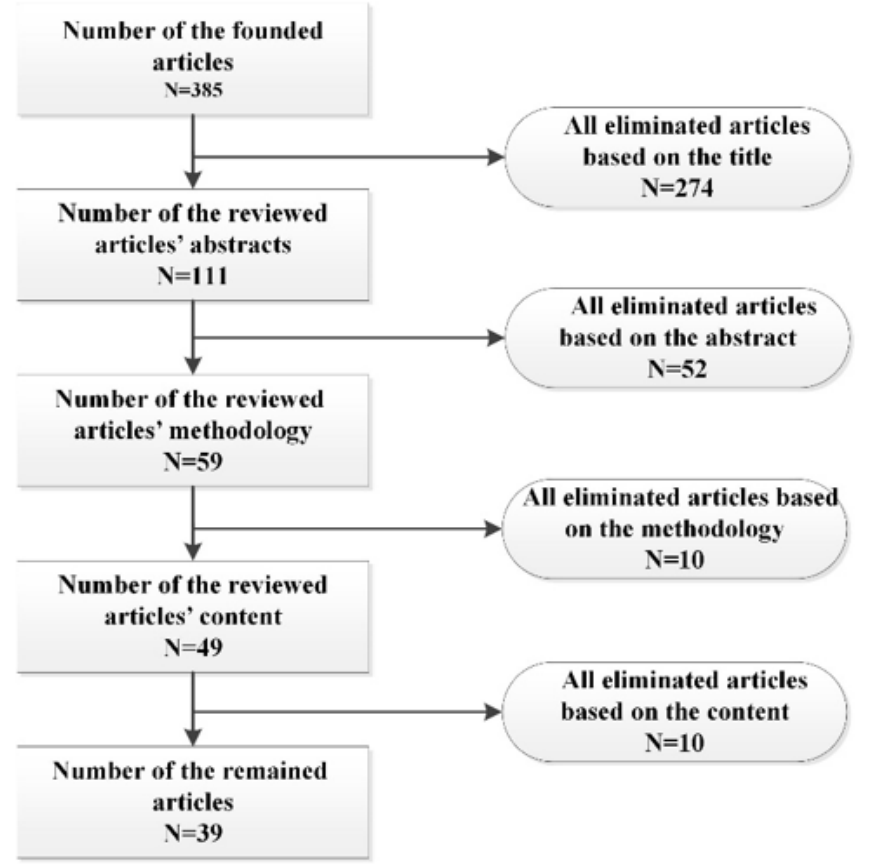


Figure 2

Process of refining the papers using the CASP method.

Figure 3

Primary model of GHRM (extracted from literature).

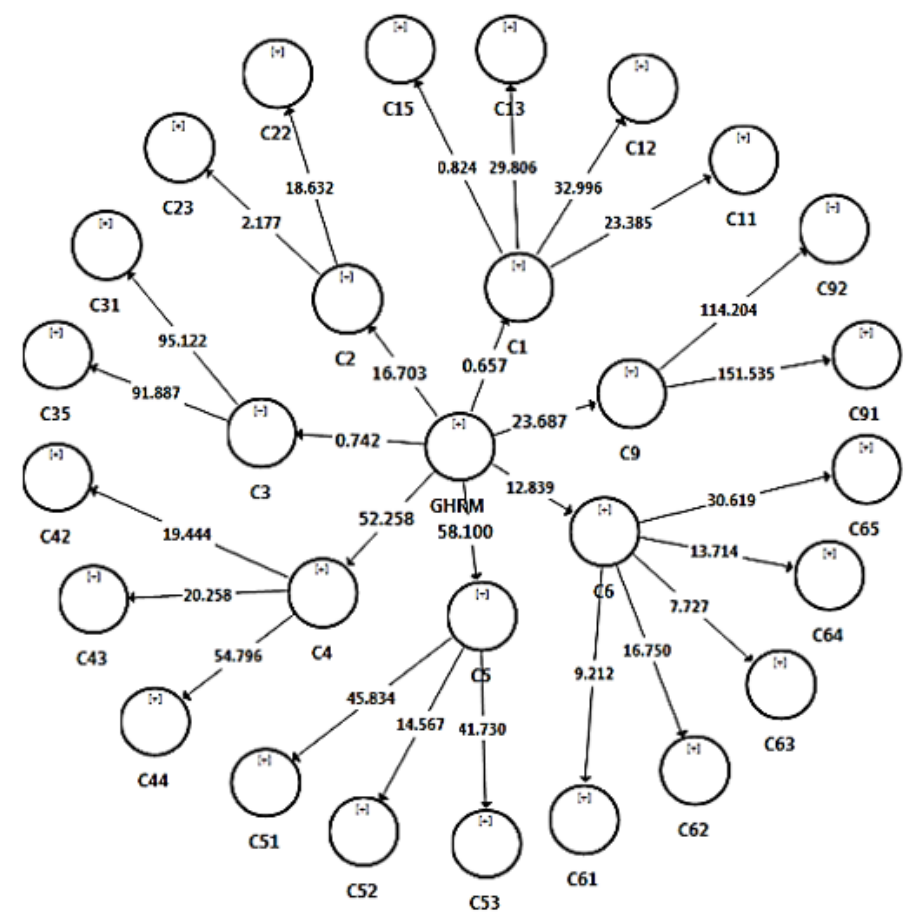

Figure 4

$t$ coefficients of the software's outputs.

Figure 5

Final model of GHRM in the construction industry. 